\title{
原著
}

高齢め屯い患者の MRI 上の大脳病変と前庭眼反射固視抑制

村井 紀彦・小田 直治

\section{Fixation Suppression of Vestibulo-ocular Reflex in Elderly Patients with Disequilibrium: Significance of Cerebral Lesions on MRI}

\author{
Norihiko Murai, Naoharu Oda \\ Department of Otolaryngology, Matsue City Hospital
}

In this retrospective study, the authors asked whether the presence of cerebral lesions (lacunar infarcts and/or white matter lesions) on magnetic resonance images (MRI) affected vestibulo-ocular reflex (VOR) gain, fixation-suppressed VOR (fVOR) gain, and visual suppression rate (VSR) in 46 elderly patients with disequilibrium symptoms treated at Department of Otolaryngology, Matsue City Hospital between January 2004 and December 2004. The VOR and fVOR were examined with manually-rotated sinusoidal stimuli using an infrared camera system. VOR gain in the dark did not differ significantly, irrespective of the MRI findings. On the other hand, fVOR gain in patients with cerebral lesions was significantly higher than that in patients without cerebral lesions, resulting in significantly lower VSR in the former patients. Impairment of visual suppression of VOR due to brain lesions outside the cerebellum or pons may not be uncommon in the elderly.

Key words: fixation suppression, vestibulo-ocluar reflex, cerebrum

\section{はじめに}

高齢者の平衡障害は多因子的であり，そのめま いの原因をひとつに特定することは難しく，診療 に難渋することがある。それらの多くの因子の中 でも，脳血管障害と頸椎の異常が高齢者に执いて は重要さを増すと言われている1。ある多施設研 究の結果では，一般人口中では，めまい患者の $50 \%$ 良性発作性頭位めまい症, 前庭神経炎やx ニエール病などの末梢前庭性疾患であったと報告 されているが2)，高齢者に限定した場合には中枢 性疾患 (18\%) や心血管系の問題が原因と考えら れる例 (36\%) が増加し，末梢前庭性疾患の比率

松江市立病院耳鼻咽喉科
（23\%）は低下するとされている3。高齢めまい 患者に括いては中枢神経系の精査がより重要性を もつことになるが，この場合の中枢神経系の放射 線学的評価は難しい。高齢者に括いては, 脳虚血, 白質病変や萎縮が，めまい症状のあるなしにかか わらず健常者に和いてもある程度指摘されらるか らである4)5)。深部白質抢上び灰白質や脳幹の穿 通動脈の虚血による，いわゆるラクネ梗塞は，日 本人の健康診断受診者集団に括いては，60歳代で は50〜60\%，70歳代以上では約75\%で発見される とする報告もある4。このような虚血巣と患者の 平衡障害症状との関連については未明な点が多い が, 両者の関連を示唆する報告も現れており さらなる検討を要する。MRI 所見と平衡障害を 
関連づける過去の報告では，単に平衡障害症状の ありなしのみが検討されており，平衡障害の定量 的指標が評価されたものは数少ない。ここで，視 覚と前庭系の共同作用（視前庭相互作用）は中枢 における統合作用に依存するため，中权性前庭障 害の評価に有用であり，前庭眼反射の固視抑制は 最も広く模查されている視前庭相互作用のひとつ である。固視抑制にかかわる中权経路の詳細は解 明されていないが，霊長類などでの破壊実験9), 臨床例での観察 ${ }^{10)}$, 脳機能画像による検討 ${ }^{11)}$ など から，視覚とその統合にかかわる多様な部位の大 脳皮質から橋被蓋網様核などの橋核を介して小脳 を経て前庭神経核と眼球運動神経核へと至る経路 が必要と考劣られている。このように多様な脳の 部位に依存する視前庭相互作用である固視抑制下 前庭眼反射は加齢によって動特性が低下していく ことが知られて扣り ${ }^{12)}$ ，加秢による脳虚血病変の 増加と関連があるかどうかも興味深い。今回我々 は，日々の外来診療中に短時間で視前庭相互作用 を評価できるシステムを用いて，多数例のめまい 症例の中枢性前庭機能の程度をスクリーニングで きたので，これらの症例の頭部 MRI 所見と前庭 眼反射固視抑制率とを対比した結果を報告する。

\section{対象と方法}

平成16年 1 月から平成16年12月をでの間に松江 市立病院耳鼻咽喉科に扣いて，簡易的手動回転刺 激による前庭眼反射固視抑制検查と頭部 MRI 検 查を施行されためまい・平衡障害症例の5ち，60 藏以上80歳未満の高柃者例46例についてレトロス ペクティブにカルテを調査することによって検討 した。明らかに末梢前庭性疾患と考兄られる症例 は除外されて括り，注かの脳神経症状，小脳症状 などの神経学的症候を有する症例も含をれていな い。垂直性眼振, 減衰㑯向のない頭位性眼振など の中枢性めまいる示唆する異常眼球運動を呈する 症例は除外されていない。葟注全例で，椎骨脳底 動脈不全症または原因不明のめまいが暫定的診断 であった。簡易的手動振子様回転刺激による前庭 眼反射とその固視抑制の検査法の詳細は過去の報 告のと打りである13)。簡潔に述べると，刺激周波 数は約 0.5 から $0.8 \mathrm{~Hz}$ ，振幅が片側約 $20 \sim 30$ 度の ヨ一方向の振子様回転刺激を手動で加之, 頭部角 速度と眼球運動角速度をモニターして解析した。 暗所での前庭眼反射（仮想注視点なし，暗算負荷
なし）を検查した後に，頭部と一緒に運動する視 標を明所で呈示できる状態にして前庭眼反射固視 抑制検査を行った。用いられた視標は眼球の約 $30 \mathrm{~cm}$ 前方に揭げられた直径約 $1 \mathrm{~cm}$ の円形視標 である。赤外線カメラシステム（モリ夕製作所 製，ニスタモ21）によって頭部運動・眼球運動の 記録・解析を行い，暗所での水平性前庭眼反射ゲ イン $\mathrm{G}_{\mathrm{d}}$ と固視抑制下の前庭眼反射ゲイン $\mathrm{G}_{\mathrm{f}}$ ，な らびに固視抑制率 $V\left(V=\left(G_{\mathrm{d}}-\mathrm{G}_{\mathrm{f}}\right) / \mathrm{G}_{\mathrm{d}} \times 100(\%)\right) を$ 計算した。頭部 MRI 検查については, T1 強調軸 位断と T2 強調軸位断を検討した。T2 強調画像 で高信号，T1 強調画像で低信号を呈し，深部白 質または灰白質に存在するラクネ病变と，T2 強 調画像で高信号, T1 強調画像では低信号となら ない皮質下白質の白質病変のうらいずれかが存在 する例を病変群に，存在しない例を非病変群に分 類した。異常信号の大きさについては直径 3 から $15 \mathrm{~mm}$ のもののみを対象とした。また小脳，橋， 脳幹部に明らかな病变を認める症例は今回の検討 からは除外されている。30歳から64歳の健常者 10 例に打いて同様の方法で過去に測定した各指標の データ13)を，非高齢健常群のデータとして利用 した。病変群, 非病変群扛よび非高龄健常群の 3 群の間で，暗所での水平性前庭眼反射ゲイン $G_{d}$ と固視抑制下の前庭眼反射ゲイン $\mathrm{G}_{\mathrm{f}}$ および固視 抑制率Vに差があるかとうかを，Bonferroni corrrection を施した Mann-Whitney U 検定によっ て検討し， $0.05 \div 3$ 未満の $p$ 值を有意とした。ま た病変群と非病変群において，検查指標と年齢の 間に相関がみられるかどらかを Spearmann rank correlationテストによって検討した。統計学的解 析はコンピュータソフト, Statistica（StatSoft, USA）を用いて行った。

\section{結 果}

前述の基準により病変ありとされた症例（病変 群）は24例であった。代表的な MRI 所見を図 1 に示す。病変の存在部位，性状见ついては，今回 は例数が少ないため，それ以上分類することはで きなかった。非病変群に分類された例数は22例で あった。いずれの群も小脳, 橋には病変を有して いない。非高齢健常群を含めた 3 群の年齢, 暗所 での水平性前庭眼反射ゲイン $G_{\mathrm{d}}$, 固視抑制下の 前庭眼反射ゲイン $\mathrm{G}_{\mathrm{f}}$, 固視抑制率 $\mathrm{V}(\%)$ の結果 要約 (平均 \pm 1 標準偏差) を表 1 に示す。表 2 は 

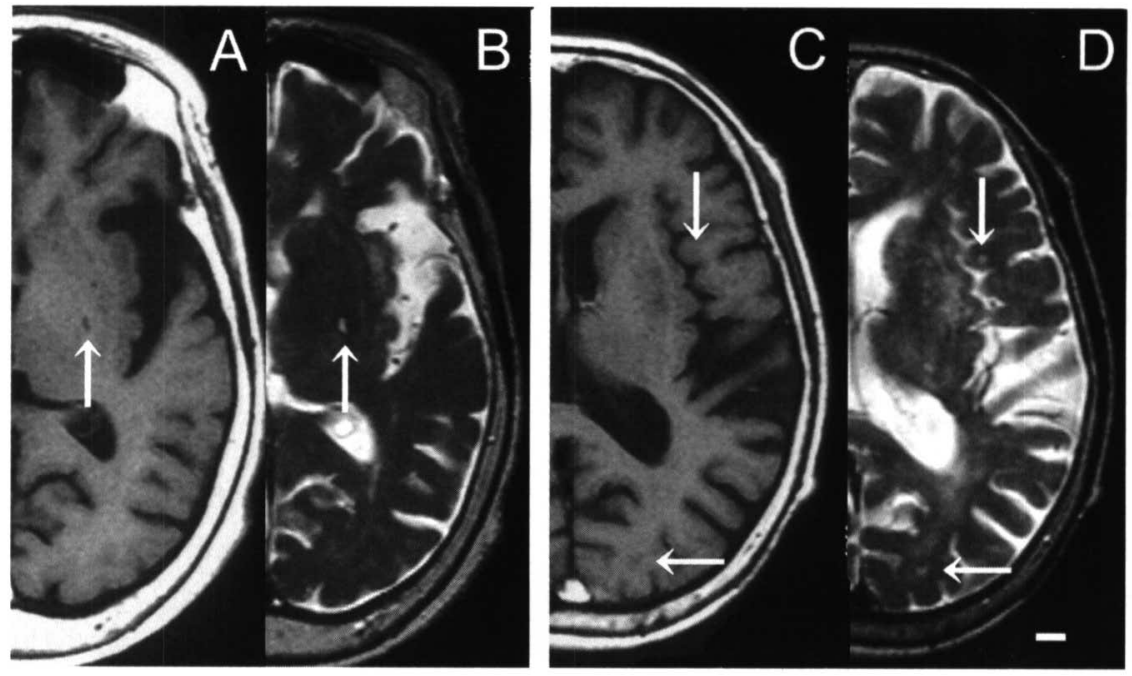

図 1 病変群例の代表的な MRI 所見

横棒は $1 \mathrm{~cm}$ 。

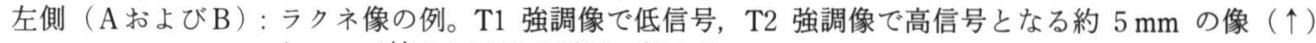
をレンズ核またはその周辺に認める。

右側 ( C お上び D ) : 白質病変の例。 T1 強調像で等信号, T2 強調像で高信号を呈する $3 \sim 4 \mathrm{~mm}$ の異常信 号（个とセ）を皮質下白質に認める。

3 群の間の相互比較に打ける $p$ 值を一覧にした ものである。病変群と非病変群の $\mathrm{G}_{\mathrm{d}}$ は, 非高齢 健常群のそれより低い傾向にあったが，有意では なかった。 $\mathrm{G}_{\mathrm{f}}$ および V は非高齢健常群と病変群 との間で比較すると, 後者に沶いて有意に悪い結
果（高 $\mathrm{G}_{\mathrm{f}}$ 杼よび低 V) であったが, 非高齡健常 群と非病変群の間では有意な差ではなかった。病 変群と非病変群で平均年齢に有意な差はみられな かった。図 2 は病変群と非病変群の暗所での水平 性前庭眼反射ゲイン $\mathrm{G}_{\mathrm{d}}$ を年㱓に対してプロット

表 1 結果の要約

\begin{tabular}{clll}
\hline & \multicolumn{1}{c}{ 非病変群 } & \multicolumn{1}{c}{ 病 変 群 } & 非高路健常群 \\
\hline 年 歯 & $67.31 \pm 6.18$ & $69.46 \pm 5.40$ & $45.50 \pm 10.02$ \\
暗所 VOR ゲイン & $0.448 \pm 0.141$ & $0.440 \pm 0.110$ & $0.521 \pm 0.111$ \\
固視抑制 VOR ゲイン & $0.127 \pm 0.076$ & $0.194 \pm 0.046$ & $0.095 \pm 0.064$ \\
固視抑制率 $(\%)$ & $71.84 \pm 13.19$ & $53.75 \pm 14.77$ & $81.45 \pm 10.33$ \\
\hline
\end{tabular}

表 23 群の間での年齢と各指標の比較

0.0167未満のp 值を棄却基準とした。下線を付した比較が有意な差のある比較。

\begin{tabular}{|c|c|c|c|}
\hline & 非高齢健常群対非病変群 & 非高齡健常群対病変群 & 非病変群対病変群 \\
\hline 年 齢 & $\leq 0.0001$ & $\leq 0.0001$ & 0.2297 \\
\hline 暗所 VOR ゲイン & 0.0804 & 0.0359 & 0.9561 \\
\hline 固視抑制 VOR ゲイン & 0.1931 & $\underline{0.0005}$ & $\underline{0.0004}$ \\
\hline 固視抑制率（\%） & 0.0296 & $\leq 0.0001$ & $\leq 0.0001$ \\
\hline
\end{tabular}




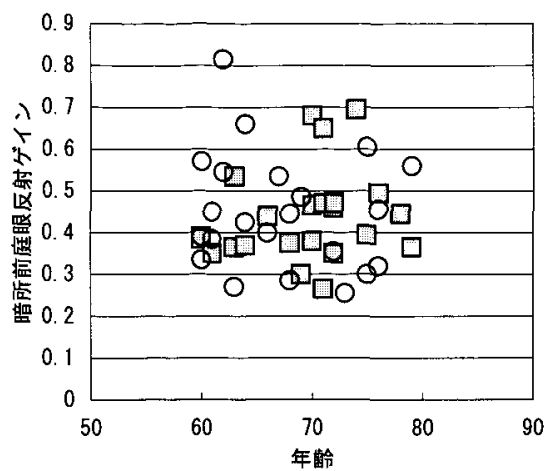

口病変群

○非病変群

図 2 暗所前庭眼反射ゲィンを年龄に対してプ ロットした散布図

○: 非病変群, $⿴$ : 病変群。

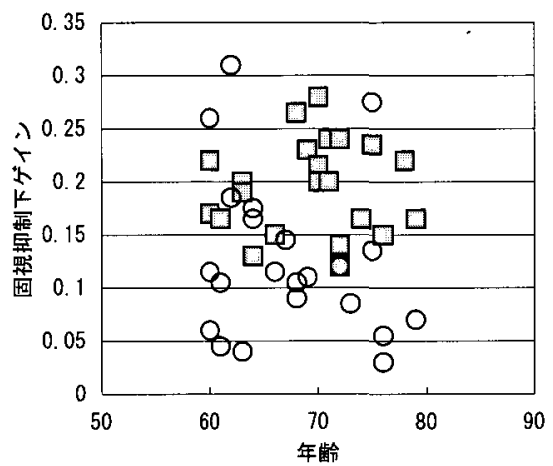

\section{四病変群}

○非病変群

図3 固視抑制下前庭眼反射ダィンを年齢に対し てプロットした散布図

$\bigcirc$ : 非病変群, 㖥 : 病変群。

図 2 とは縦軸のスケールが異なっている。

した図である。表 1,2 に示すと扣り $\mathrm{G}_{\mathrm{d}}$ は病変 群と非病変群の間に差はみられなかった。図 3 は 病変群と非病変群の固視抑制下の前庭眼反射ゲイ

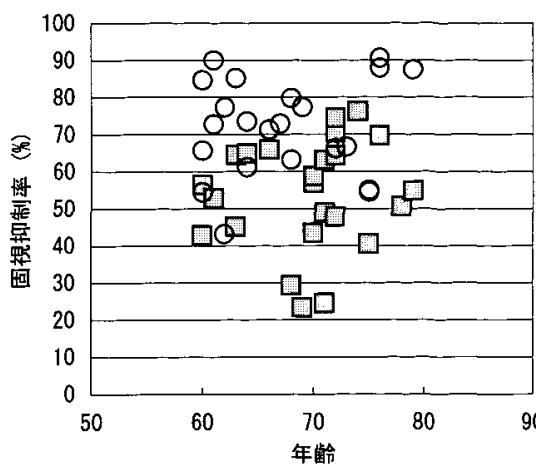

口病変群 ○非病変群

図 4 前庭眼反射固視抑制率を年龄に対してプ ロットした散布図

$\bigcirc$ : 非病変群, $\square$ : 病変群。

ン $\mathrm{G}_{\mathrm{f}}$ を年龄に対してプロットした図である。表 1,2 に示すと叔り病変群では有意に非病変群よ りも $\mathrm{G}_{\mathrm{f}}$ の值が高くなって括り $(p<0.001)$, 病 変群に含まれる症例において前庭眼反射の中枢性 制御が, 非病変群の症例よりも障害されているこ とが明らかになった。図 4 は同様に病変群と非病 変群の固視抑制率 V(\%) を年齢に対してプロッ トした図である。固視抑制率 Vの定義から考克 て明らかであるが， $\mathrm{G}_{\mathrm{f}}$ の值と同様注変群の成 績が非病変群よりも有意に悪い結果となった（ $p$ $<0.001)$ 。表 3 は病変群と非病変群に打いて，年 齢と各検査指標の間の相関を検討した結果を示す が，今回検討した60歳以上80歳未満といら狭い年 龄域においては，図 2 から 4 に打ける各群のプ ロットのいずれにおいても，各検査指標之年龄之 の間に有意な相関は認められなかった。

\section{考察}

前庭眼反射の固視抑制率の低下は小脳小節，片

表 3 各検査指標と年柃の間の相関の有無

\begin{tabular}{cccc}
\hline 非病変群 & 固視抑制率 & 暗所前庭眼反射ゲイン & 固視抑制下ゲイン \\
相関係数 & 0.13531 & -0.15345 & -0.22179 \\
$p$ 值 & $<0.548$ & $<0.495$ & $<0.321$ \\
\hline 病変群 & & & \\
& 固視抑制率 & 暗所前庭眼反射ゲイン & 固視抑制下ゲィン \\
相関係数 & 0.11006 & 0.21584 & 0.03115 \\
$p$ 值 & $<0.609$ & $<0.311$ & $<0.885$ \\
\hline
\end{tabular}


葉，橋の障害で起こるとされているほか，大脳， ことに下頭頂葉での障害によっても生じることが 報告されている。この部位は視覚情報と運動の指 令を統合する Brodmann 第 7 野を含导頭頂連合野 に関連するものと考えられる10)。さらにPETに よる脳機能画像検查を用いて, 温度刺激眼振の固 視抑制タスクによって賦活化される大脳の部位を 検討した研究に上れば，一次視覚野と，舌上回， 紡釷回（第17，18，19野）含む後頙連合野，視 覚情報の統合を行ら下側頭連合野（第20野など）， 前頭眼野（第 8 野）なども，固視抑制に関与し5 ることが知られている11\%。このような視覚情報の 処理・統合に関する部位，さらにそれらを連絡す る経路を含めると，極めて多様な部位がこのタス クに必要であることがわかる。

今回の検討では，大脳病変の存在部位は詳細に 分類されて扣らず，また病变の性質に批いても異 質な病態のものが湿在しているにもかかわらず， 高齢如患者の大脳病变と前庭眼反射固視抑制 の間に何らかの関連があることがわかった。この ことはいくつかの可能性を示唆する。ひとつは， 固視抑制が視覚情報の処理とその運動との統合に かかわる，大脳の広、範囲の部位に依存している ために，小脳や橋以外の病変であっても，患者の 平衡障害症状に何らかの影響を与えているといら 可能性である。もうひとつは，大脳の病変は直接 に平衡障害症状とは関係がないが，そのような例 では橋などの固視抑制にかかわる大脳以外の部位 にも，今回のょらな撮像法では明らかにしえない ような微少な病変があって，それが症状と関係し ているとするものである。いずれにしても，前庭 眼反射固視抑制の異常が小脳や橋の障害だけでな く，脳血管障害などを原因とする脳病変による平 衡障害の指標にもなる可能性が示唆された。高粭 の症例では末梢前庭系の障害に加えて，末梢前庭 や固有知覚器からの情報処理の遅延化なぞの前庭 中权路の機能低下があることを示唆する報告があ $り^{14)}$ ，また平衡障害症状の有無とMRI 所見を対 比した過去の報告の中には，梗塞像よりも白質病 変が平衡障害症状と関係があるとするもの ${ }^{8)}$ ， た部位としては中脳の白質病変が重要とするもの

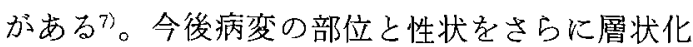
し，どの部位のどのような性状の病変が，この視 前庭相互作用の障害と関係があるのかを検討して
いく必要があると思われる。Baloh ら ${ }^{12)}$ は高龄者 の固視抑制下前庭眼反射ゲインを縦断的に追跡 し，5年間で有意なゲインの上昇を確認している。 また, Paige ${ }^{15)}$ は高路者と非高跉者を横断的に比 較し，刺激周波数によって違いがあるものの，暗 所での水平性前庭眼反射ゲインは差はないが，固 視抑制下の前庭眼反射グインは高秢者で悪化する 場合があることを示している。今回の検討では非 病変群で, 非高齢健常群に較べて暗所での水平性 前庭眼反射ゲイン，固視抑制下の前庭眼反射ゲイ ンともに有意ではなかったが低い傾向にはあっ た。症状の有無といら因子が違らため，その意義 は明らかでないが今後さらに検討すべきと考光ら れる。

本論文の要旨は第14回日本耳科学会総会学術講 演会（平成16年10月，京都）に蛒いてロ演した。

謝辞

堀郁子先生（松汇市立病院放射線科）と, 藤 原三津子氏（松江市立病院臨床検查科）に深謝致 します。

文献

1) Salles N, Kressig RW, Michel JP: Management of chronic dizziness in elderly people. $Z$ Gerontol Geriatr 36: 10-15, 2003

2 ) Delaney KA: Bedside diagnosis of vertigo: value of the history and neurological examination. Acad Emerg Med 10: 1388-1395, 2003

3 ) Lawson J, Fitzgerald J, Birchall J, et al: Diagnosis of geriatric patients with severe dizziness. J Am Geriatr Soc 47: 12-17, 1999

4) 吉武泰男, 高松慶太: 統計からみた脳梗塞予 防についての考察. 医事新法 4153: 46-50, 2003

5) Ylikoski A, Erkinjuntti T, Raininko R, et al: White matter hyperintensities on MRI in the neurologically nondiseased elderly. Analysis of cohorts of consecutive subjects aged 55 to 85 years living at home. Stroke 26: 1171-1177, 1995

6) Kerber KA, Enrietto JA, Jacobson KM, et al: Disequilibrium in older people: a prospective study. Neurology 51: 574-580, 1998

7 ) Colledge N, Lewis S, Mead G, et al: Magnetic 
resonance brain imaging in people with dizziness: a comparison with non-dizzy people. J Neurol Neurosurg Psychiatry 72: 587-589, 2002

8) Fujishima M, Yao $H$, Terashi A, et al: Deep white matter lesions on MRI, and not silent brain infarcts are related to headache and dizziness of non-specific cause in non-stroke Japanese subjects. Intern Med 39: 727-731, 2000

9 ) Takemori S, Cohen B: Loss of visual suppression of vestibular nystagmus after flocculus lesions. Brain Res 72: 213-224, 1974

10) Takemori $S$, Ono M, Maeda T: Cerebral contribution to the visual suppression of vestibular nystagmus. Arch Otolaryngol 105: 579-581, 1979

11) Naito $Y$, Tateya I, Hirano $S$, et al: Cortical correlates of vestibulo-ocular reflex modulation: a PET study. Brain 126: 1562-1578, 2003

12) Baloh RW, Enrietto J, Jacobson KM, et al: Age- related changes in vestibular function: a longitudinal study. Ann N Y Acad Sci 942: 210-219, 2001

13) Murai N, Funabiki K, Naito $Y$, et al: Validity and limitation of manual rotational test to detect impaired visual-vestibular interaction due to cerebellar disorders. Auris Nasus Larynx 32: 23-28, 2005

14) Wolfson L, Whipple R, Derby CA, et al: A dynamic posturography study of balance in healthy elderly. Neurology 42: 2069-2075, 1992

15) Paige GD: Senescence of human visual-vestibular interactions: smooth pursuit, optokinetic, and vestibular control of eye movements with aging. Exp Brain Res 98: 355-372, 1994

\footnotetext{
原稿到着 : 平成17年 1 月 13 日

別刷請求先 : 村井紀彦

=690-8509 島根県松江市乃白町32-1

松江市立病院耳鼻咽喉科
} 